\title{
Political instability and sustainable green supply chain management
}

\author{
Najwan Jadallah $^{\mathbf{a}^{*}}$ and Feyza Bhatti ${ }^{\mathrm{b}}$
}

${ }^{a}$ Palestinian Agricultural and Risk Reduction Fund, Palestine

${ }^{b}$ Girne American University, Cyprus

CH R O N I C L E

\begin{tabular}{l}
\hline Article history: \\
Received: October 30, 2019 \\
Received in revised format: No- \\
vember 282019 \\
Accepted: December 2, 2019 \\
Available online: \\
December 2, 2019 \\
\hline Keywords: \\
Political instability \\
Sustainable supply chain manage- \\
ment \\
Palestine \\
Green practices \\
\hline
\end{tabular}

\begin{abstract}
A B S T R A C T
In this paper, the relationship between political instability and sustainable supply chain management is examined within the context of Palestine. This is due to the fact that instable state has created a chaotic situation for manufacturers. This paper tends to this subject through quantitative measures from the perspective of employees. A number of 265 employees were selected in manufacturing organizations of Palestine, in which sustainable supply chain practices were found to be in the mindset of managers and have been shared with employees and/or the practices are implemented within the firm. This study uses statistical analyses (ANOVA and Correlation analysis) alongside construct reliability and factor loadings to test proposed hypotheses. Results of the analysis show a significant negative effect from political instability and its dimension upon sustainable supply chain management practices and their implementation that is perceived by the employees. Contributions of this papers are threefold as the literature lacks direct examination of current factors, instable countries such as Palestine have not been examined in terms of sustainable supply chain, and managers can benefit from importance of various factors of sustainable practices of supply chain.
\end{abstract}

\section{Introduction}

In this paper, the relationship between political instability and sustainable supply chain management is examined within the context of Palestine. This is due to the fact that instable state has created a chaotic situation for manufacturers. This paper tends to this subject through quantitative measures from the employees' perspective. Concepts and research framework are further explained in details. Political instability as a concept calls for further examination and investigation as the notion is complex in its nature and its existence obstacles path towards conduction of comprehensive research on a full scale. The literature lacks to identify key aspects and variables in terms of political instability and its linkage with green/sustainable practices of SCM. This further becomes more explicit as countries with political instability have been somewhat neglected in terms of research. Thus, the current paper tends to contribute to the literature of the topic through conduction of this study in the context of Palestine as a state with political instability. This can be beneficial for both internal and external parties regarding consideration of green initiatives, when it comes to instable states. It is highly important to note that similar states and countries require such studies to further advance towards sustainability. Political instability requires further examination and research to be conducted due to its complex nature and the fact that this subject has not been thoroughly discussed in relation with green practices. Particularly, SSCM practices and their implementation within countries with political instability calls scholars to pay more attention to advancements of sustainable-related change on a global scale. Hence, current paper tends to examine the aforementioned relationship in this context.

\section{Supply Chain Management}

It has been stated that due to increasing level of competitiveness within markets in the current century, companies and especially manufacturers have been challenged with constant changes in the global market. This puts a pressure on production of

* Corresponding author.

E-mail address: eng.najwan@yahoo.com (N. Jadallah) 
goods as manufacturers are consequently to reflect the expiry date of their products. Customer expectations change on a constant manner and on a fast-pace, which can be seen from the market and the goods that are highly accessible with a correlated high demand and are timely considered (Huxel \& Gelashvili, 2014). From organizational view, flexibility is a key matter in terms of maintaining sustainable competitiveness in terms of change within the global market. Although it has been mentioned that for survival within this market, supply chain and its proper management is a key factor (Ugochukwu et al., 2012), it is also important to note the external factors, which influence an organization to a great level. Such factors can be the state of the society or nation that a specific organization is located in. To be specific, political state of a society is a substantial element, which can play a provider role as well as a constraint.

Supply chain as a concept, addresses functions that include raw material to assembly lines and towards manufacturing procedures (Russel \& Taylor, 2009). It is important to note the complex nature of this subject and its various elemental factors that are directly or indirectly impactful (e.g. manufacturing, sales, purchases, and distribution systems). Therefore, it can be said that the term supply chain management, addresses managing the aforementioned functions. The flow of meeting demands on a timely manner and fulfillment of customer needs and wants are enhanced through the process of supply chain management. This include price adjustment and a functional process that is desirable (Collier \& Evans, 2009). Reduction of costs, enhanced delivery and acceptable quality of goods is a major focus among the experts of supply chain management (Janvier-James, 2012). Each and every process within supply chain management (SCM) consists of a number of individuals. New order placements, shipments, preparation (storages), billing, transport, and other necessary or required documents are among the said processes (G\&D Integrated, 2015). These processes are to be optimized and function efficiently for organizations to survive and to further thrive within global markets.

\section{Green and Lean SCM}

With increased degree of global awareness and great deal of attention towards sustainability and environmentally friendly activities, and with regards to the fact that a significant number of firms face challenges in this context, green and lean SCM has been emerged (McKinsey, 2010). New regulations, high levels of societal pressures and newly formed competitive market raise a considerable pressure on firms in terms of economic and environmental aspects (Bai et al., 2015). Companies and manufacturers can have vivid impacts on environment through proper implication of sustainable functions, such as SCM. This notion has received support within the literature of the subject (e.g. Kurdve et al., 2014; Tseng et al., 2014b; Tseng et al., 2015). China as a major manufacturer on a global scale has faced environmental issues on a great scale in accordance with its development of economics (Zhu et al., 2012). Accordingly, China is among the top polluters of environment due to its highly advance manufacturing, which has led the country to be top ocean polluter in recent years (Ocean Conservation Research, 2018). This is while China initiated a sustainable development plan in the 90 s to move towards a more sustainable manufacturing, which aids economics as well as environment in terms of production and efficiency (Economy, 2007; Bai et al., 2015; Zhu et al., 2012). Increased production quality and productivity, cut-off inventories, and time management are pillars of lean manufacturing, which has been derived from Toyota, Japan and has become an important concept (Garza-Reyes et al., 2012). Both customers and environment have been taken into consideration in reviewing policies and regulations regarding organizations and their compliance with issued regulations in terms of functions and processes. Green SCM is a similar aspect, from which environment and related activities are emphasized to reach higher levels in terms of efficiency and implications with consideration of SCM (Azevedo et al., 2012; Kurdve et al., 2014). Through these initiatives, costs can be lowered and waste production can be decreased on a significant level. This entails production efficiency, value provision to customers and efficient consumption and usage of resources (Pakdil \& Leonard, 2014; Tseng et al., 2015). When these two concepts are combined, new functions and procedures are to be recognized and further developed (Duarte \& Cruz-Machado, 2013, 2015). Significant impact of lean and green SCM has been noted within the literature of the subject (e.g. Dues et al., 2013; Duarte and Cruz-Machado, 2015; Garza-Reyes, 2015; Pampanelli et al., 2014; Kurdve et al., 2014).

\section{Sustainable SCM}

Sustainable Supply Chain Management (hereafter SSCM) faced a drastic change after the World Summit of UN in 2005 regarding environment and development. A surge of awareness as well as critical attention has been flown towards the subject of sustainability as the number of people concerned about the environment is increasing and movements have forced governments to take action regarding policies and regulations. Creation of profit as well as progress for societies along with environmental protection is henceforth, reached to all subjects from all aspects. Sustainable development in context of logistics and supply chain has been categorized into four distinctive groups that are risk management, transparency, strategy, and culture (Carter \& Rogers, 2008). Following what was mentioned before, a variety of subjects have been linked to SSCM such as, corporate social responsibility (Keating et al., 2008); environmental logistics (Wu \& Dunn, 1995); green logistics (McKinnon et al., 2010); Social media (Cox \& Atkinson, 2018); and technological barriers (Kumar et al., 2013, 2014). Although various aspects of SSCM have been noted in the literature and examined against a number of organizational factors, the notion faces a lack of extensive attention in the context of political instability and the extent of which SSCM can be affected by political instability. This especially becomes important as notable amounts of manufacturers in Palestine have changed their systems towards more sustainable and green initiatives. This is while not only the political state of the country is important for proper implementation and functioning of sustainable initiative, but further uncertain challenges enforced by the global trade systems adds extra challenges for such firms in instable states (Housyar et al., 2013). Changes within demand is an influential factor that is teamed with disruptions of transportation particularly, where political instability is observed, alongside 
natural disasters can negatively impact supply chain and individuals in the chain industry (Azman \& Jaafar, 2018). For manufacturers and environmentally friendly activities initiated by them, logistic service providers and considering them as a substitute for chain value has been proposed by Huemer (2012), which further entails logistic services and addresses sustainability challenges (Philipp \& Militaru, 2011). The current article follows the line of attention, which has been given to SSCM in the recent years (i.e. Dubey et al., 2017) against the effects that are implied through political instability, which has relatively received lesser attention from scholars (e.g. Kumar et al., 2015; Cox \& Atkinson, 2018). This lack is further vivid for the case of Palestine despite its political instability. Hence, this paper tends to the aforementioned notion in this context. Furthermore, both Green and Sustainable SCM address the same notion of having implemented all activities that are environmentally friendly and aid protecting the planet. Thus, both terms are referred in this article as SSCM or GSCM.

\section{SSCM Critical Success Factors}

Through reviewing the literature of the topic, most relevant and recent critical success factors for implementation of GSCM within a manufacturing company have been identified. However, the study examines disruptions of GSCM and specifically, political instability within Palestine. These factors are: International environmental agreements (Ketikidis et al., 2013; Luthra et al., 2011; Luthra et al., 2013); Legislations issued by central government (Balasubramanian, 2012; Qadri et al., 2011); Legislations issued by government (Luthra et al., 2010, 2011). Non-governmental Organizations (NGOs) (Kong et al., 2003); Suppliers involved in sustainable and green practices (Agarwal \& Vijayvargy, 2012; Wang \& Gupta, 2011); Suppliers with training campaigns (Luthra et al., 2013; Wu et al., 2012); Transference of technologies to suppliers (Andiç et al., 2012; More \& Mateen, 2012); Level of commitment and initiatives of managers (Green et al., 2012; Luthra et al., 2013; Walker \& Jones, 2012); Internal SSCM/GSCM regulations and policies (Toppinen \& Korhonen-Kurki, 2013); Planning efficient strategic systems (Büyüközkan \& Cifci, 2012; Chan et al., 2012; Dangayach \& Laosirihongthong, 2012). Advancements and adaptation of technology (Andiç et al., 2012; Luthra et al., 2013; Muduli \& Barve, 2011); Information Technology (IT) functioning level (Chan et al., 2012; Green et al., 2012; Luthra et al., 2013; Tseng et al., 2011); Quality of shared information (Wu \& Hang, 2009); SRHRM practices (Lazuraz et al., 2011; Luthra et al., 2013); Awareness of supply chain crew (Toke et al., 2012; Wu et al., 2012). Employee involvement in SSCM practices (Luthra et al., 2011); Workplace management and its efficiency (Toke et al., 2012); Economic interests (Luthra et al., 2011); Cost of hazardous materials (Simpson \& Samson, 2008). Competitiveness of the market (Nimawat \& Namdev, 2012; Lee et al., 2013); Customers' awareness of SSCM (Luthra et al., 2013); Brand image (Lin, 2011); Customers' support for the organization (Green et al., 2012); Customers' degree of motivation for organization (Reijonen, 2011; Toke et al., 2010); Social concerns (Qadri et al., 2011; Sarkis, 2012); and Abundance or scarcity of natural resources (Qadri et al., 2011). It is key to highlight the fact that governments' role and degree of involvement with GSCM practices and their implementation is a vital element (Lee, 2008). In a study conducted by Shang et al. (2010) the number of these factors have been reduced to six after Confirmatory Factor Analysis. Nonetheless, our study follows the framework suggested by Luthra et al. $(2014,2015)$ and Luthra and Haleem (2015) regarding GSCM practices. Through this framework, SSCM practices have been categorized into six groups that are namely, green design, green purchasing, green production, green management, green marketing, and green logistics. SSCM related studies have been conducted in other geographical contexts such as Turkey, Italy, US, China, and Korea. However, the subject of political instability and its relationship with SSCM practices has not been investigated in a case, where the degree of instability is clearly vivid.

\section{Disruptions of GSCM - Political Instability}

SSCM and its implication can be disrupted by a number of factors. Occurrence of such disruptions consumes resources in terms of economic and can cause delays in meeting the needs of customers (Blackhurst et al., 2005; Cox \& Atkinson, 2018). Table 1 of this study presents a list of disruptions, which can be influential on GSCM and its implication. As previously mentioned, political instability is among the key elements that can have a significant impact on supply chain and subsequently, GSCM. It is noteworthy that the literature upon the subject at hand is scarce and particularly, for the case of Palestine. Hence, the current study endeavors to further shine light upon the topic at hand. In terms of GSCM and the effects of political issues, a review on the existing literature has been conducted. Politics of a country is the key predictor of the extent of which GSCM/SSCM practices are implemented within that country. Political instability plays a major role as an obstacle regarding sufficient support and its provision to regulations issued by authorities (Govindan et al., 2014). Similarly, political instability has been found to be of significance in terms of restraining and disrupting green/sustainable issuance of policies (Luthra et al., 2015, 2016; Kumar et al., 2014). It has been noted that innovative technology and its access and transfer is highly dependent on political emphasis and degree of credibility regarding management of projects (Markham, 2000; Kumar et al., 2015). This is to be regarded as a political barrier, which can affect financing projects, delivery means and R\&D initiatives between receiving and providing parties (Castells, 2005). The degree of which political power of the state is eager for effective management of GSCM is thus, a vital element in this regard. Similarly, another political barrier can be inactive role of agent, from whom the transference of technological goods can be conducted successfully. Agents carry a key role in this context as they are involved with the initial stages of the process as well as its implementation. Agents carry out details and specifics of procedures until the delivery good is handed (Proto et al., 2012). Additionally, a satisfactory level of collaboration should exist between the government and research facilities, which leads to smoother development process, especially for developing countries (Kirkland, 1996; Kumar et al., 2015). Furthermore, it was found that the extent of public pressure alongside issuance of regulations are crucial for transference of technologies, which are environmentally friendly (Cetindamar, 2001). Adequate regulations addressing sustainability can be pressured through public voice and increase collaboration between government 
and relevant institutions. The degree of political instability within a country is another major element that is influential for SSCM, its implementation, and its processes as well as development. Existence of local political issues can be regarded as a top constraint regarding transference of technologies into the borders (Chaaban \& Akkawi, 2013). Hence, in those countries, where political state is instable or chaotic, technologies that are suitable for sustainable initiatives are limited in terms of being delivered. Thus, manufacturers and organizations have a difficulty regarding proper implementation of change in their businesses. This becomes more vivid in the states that are developing, and have issues with policy enforcement (Shujing, 2012; Kumar et al., 2015). Nevertheless, political instability can greatly impact businesses from various aspects. Particularly, SSCM and its practices face a great deal of limitation as meeting demands of sustainability becomes relatively harder for the case of Palestine. This is while manufacturers have taken initiative regarding sustainable and environmentally friendly activities on a notable scale. Political barriers have been a key player in terms of having access to proper and modern technologies, which allow producers and suppliers to further advance their systems and be in line with reduction of emissions on a global scale. It has been reported that political instability and its degree within a country is a key determinant of technological transference into the borders of that country (Kumar et al., 2015). It can be said that internal political instability further complicates the international trade and political image of the said country on international scale. Political instability requires further examination and research to be conducted due to its complex nature and the fact that this subject has not been thoroughly discussed in relation with green practices. Particularly, SSCM practices and their implementation within countries with political instability calls scholars to pay more attention to advancements of sustainable-related change on a global scale. Political instability has been noted to be a concept to be regarded from indirect empirical evidence (Seddighi \& Shearing, 1997). As the literature lacks dimensional identification of political instability in every aspect, the current paper follows the work of Seddighi et al. (2002). Their proposed framework regards political instability in terms of dimension, which is gathered from a number of aspects such as, political violence, and terrorism (See Seddighi et al., 2002).

Table 1

Political Instability Dimensions

\begin{tabular}{|c|c|c|}
\hline $\mathrm{N}$ & INDICATOR & DEFINITION \\
\hline 1 & Terrorist attacks & Terrorist attacks that are covered by local or international media. \\
\hline 2 & Armed attack events & Acts of violence committed by organized groups to hinder the power of another group. \\
\hline 3 & Assassinations (political) & Any politically motivated murder or attempted murder of national government leaders or other political parties. \\
\hline 4 & Bombings & Typically an explosive triggered by a timing mechanism in a location. \\
\hline 5 & Change in government & Any significant change within the council or central governmental powers. \\
\hline 6 & $\begin{array}{l}\text { Change in political party } \\
\text { governing a country }\end{array}$ & $\begin{array}{l}\text { Regular change in office of the chief executive, excluding renewals of office by the same person or party, and } \\
\text { changes in factional coalition, where a new group is given a share of power or an old one is removed. }\end{array}$ \\
\hline 7 & Civil War & Civil War is typically fruit of a form of revolution. \\
\hline 8 & Guerilla Warfare & Combat operations in enemy-held territory (irregular forces on military or paramilitary basis) \\
\hline 9 & Hijacking & The illegal seizure of aircraft, land vehicle or other conveyance. \\
\hline 10 & Kidnappings & The unlawful taking away of a person against their will. \\
\hline 11 & Peaceful Demonstration & A non-violent gathering of people who protest against government. \\
\hline 12 & Peaceful Strikes & A work stoppage by industrial or service workers or academic life by students to protest against government \\
\hline 13 & Riots & Is a demonstration that has a violent nature, and the use of physical force is present. \\
\hline 14 & Successful coup & Change of power through abnormal or illegal institutional channels of a country \\
\hline 15 & Mass Arrests & The regular arrest of large groups of people \\
\hline 16 & $\begin{array}{l}\text { Political Instability in } \\
\text { neighboring countries }\end{array}$ & The existence of any acts of political instability in a neighboring state to the country under investigation. \\
\hline 17 & Threat of war & $\begin{array}{l}\text { Official diplomatic communication that if a particular country does not do a particular thing, it will be followed } \\
\text { by negative actions. }\end{array}$ \\
\hline 18 & Unsuccessful coup & The unsuccessful use of violence by elements functioning outside normal and legal channels \\
\hline 19 & War & Military clash between a particular country \\
\hline 21 & Censoring of Media & Actions by the authorities of a particular country to limit the mass media \\
\hline 22 & Imposition of martial law & General restrictive measures for domestic security and institution of a curfew. \\
\hline 23 & Restriction of political rights & Actions specifically directed against political rights of an individual, party or other political organizations \\
\hline 24 & $\begin{array}{l}\text { War in a neighboring } \\
\text { country }\end{array}$ & A military clash nearby the investigated country \\
\hline 25 & Arrests of significant people & The arrest of political opposition leaders \\
\hline 26 & $\begin{array}{l}\text { Terrorist attacks or threats } \\
\text { of attacks }\end{array}$ & Various types of terrorist attacks that cannot be classified \\
\hline 27 & $\begin{array}{l}\text { Army attacks beyond coun- } \\
\text { try's borders }\end{array}$ & Military clashes of the army outside of its internationally recognized territories. \\
\hline 28 & Political illegal executions & The systematic elimination by execution of political opposition \\
\hline
\end{tabular}

Following what was mentioned above, political instability can be regarded as a factor, which leads to societal, environmental and economic issues. In oil and gas industry, development and cooperation were found to be influenced negatively by political instability, which in turn has led to lack of security for supply of energy (Correlje \& Van Der Linde, 2006; Ahmad et al., 2017). Furthermore, it was noted that in countries, where oil and gas play a major role regarding dependency, failure of policies is more probable to occur. This occurrence yields in decreased economic growth as well as diminished social development. Failure of policies can further add to conflicts and political instability. Through the existence of instability in politics, a state will have uncertain situations and atmosphere for conduction of business. This in turn affects financial gains, ecological issues, safety of infrastructure and puts employees at risk. It was then reported that manufacturers and oil and gas companies consider political instability more significant and impactful, compared to economic condition of the state as political instability 
hinders supply chain and its sustainability on a greater scale (Al-Damkhi et al., 2009; Ahmad et al., 2017). Based on Table 1 of this study, and following the work of Seddighi et al. (2002), political instability has been categorized into four distinctive groups that are shown in Fig. 1.

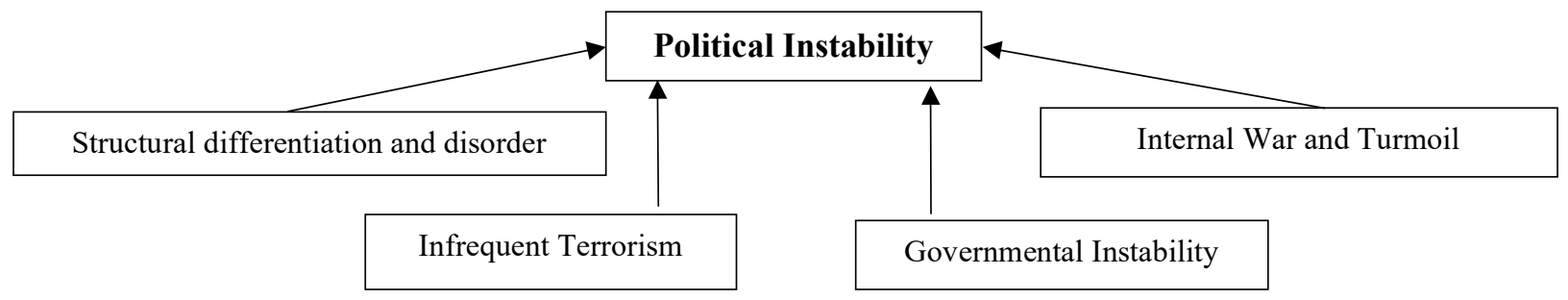

Fig. 1. Political Instability Dimensions

Similar to what was mentioned above, war, civil conflicts, political isntability, regime changes, revolutions, terrorist attacks, restrictions of export/import, obstacles for trade routes, sanctions, monopolistic practices and/or cartel existence are among the risks that face supply chain management are among political factors, which are highly influential (Fattouh, 2007; Doukas et al., 2011). Moreover, socio-political isntability has increased in the recent years and this particularly, is vivid within the context of this study as Palestine has been challenged with political and social instability in recent years (e.g. civil unrest, insurgency, protest, riot, and revolution). It has been noted that supply chain practices can be greatly influence by aforementioend elements, especially in the manufacturing industry (i.e. oil and gas-related products).

In the light of what was mentioned above, the following hypothesis has emerged:

Hypothesis: Political Instability has a negative effect on SSCM practices and its implementation.

This hypothesis turns into four sub-hypothesese, that are as following:

H1: Structural differentiation and disorder negatively impacts SSCM practices and implementation;

H2: Infrequent terrorism has a negative impact on SSCM practices and implementation;

H3: Governmental Instability has a negative impact on SSCM;

H4: Internal was and turmoil has a negative linkage with SSCM.

\section{Study Setting}

This study addresses political instability and its relationship with SSCM practices and implementation from employee perspective in manufacturing industry of Palestine. Comnsidering political issues that face the nation, manufacturerers have taken initiative regarding sustainable activities and green practices. In-perosn meetings with a number of managers in several factories was initiated by the researcher. Through these meetings, basic information regarding managements' perspective towards sustainability was questioned and the extent of which sustainable practices were initiated within the organization was addressed. As this study examines employee perspective upon the matter, a total number of 265 employees were selected from five different manufacturing units, in which sustainable practices and SSCM were found to exist based on the model propose by Luthra et al. (2015). Relevant supervisors and managers were informed about conduction of the research and its purpose and adequate permissions were granted. Participation in the survey was completely voluntary and respondents were chosen based on Convenience. Additionally, each participant was provided with relevant information throughout the data collection. as current paper examines political isntability and its linkage with SSCM practices within manufacturing industries and from employee perspective, selection of employees was merely from the companies, in which dimensions of SSCM were visible. Commonly, quantitative measures are used for SSCM research (Kumar et al., 2013; Sundarakani et al., 2010; Van der Vorst et al., 2009; Seuring \& Müller, 2008b; Kotzab et al., 2006).

\section{Survey}

A self-administered survey was designed for purpose of this study. The measurements of this survey were chosen from the most recent and relevant work of experts in the field. Luthra et al.'s (2016) scale of GSCM was used to measure the extent of these practices. A five-item Likert scale was designed for this measurement with values of $1=$ strongly disagree, $2=$ disagree, 3 = neutal, $4=$ agree, and 5 = strongly disagree. Additionally, political instability scale was derived from the work of Seddighi et al. (2002). Similarly, a five-point Likert scale was used to address the dimensions of political instability (PI) from very important, to unimportant. 28 Dimensions of political instability were then transformed into four categories presented in Fig. 1. Additionally, the survey was translated into Arabic for ease of participants through one translator and then it was translated back into English using a second translator to lower bias risks. No direct questions of religion, income or other sensitive questions were involved in the survey to furher lower respondent bias. Furthermore, the survey was designed anonymously and respondents were informed of data confidentiality. Factor loading, AVE, reliability analysis, and regression analysis 
(ANOVA) was conducted on the gathered data to analyze current theoretical model. Fig. 2 presents the proposed model of this paper.

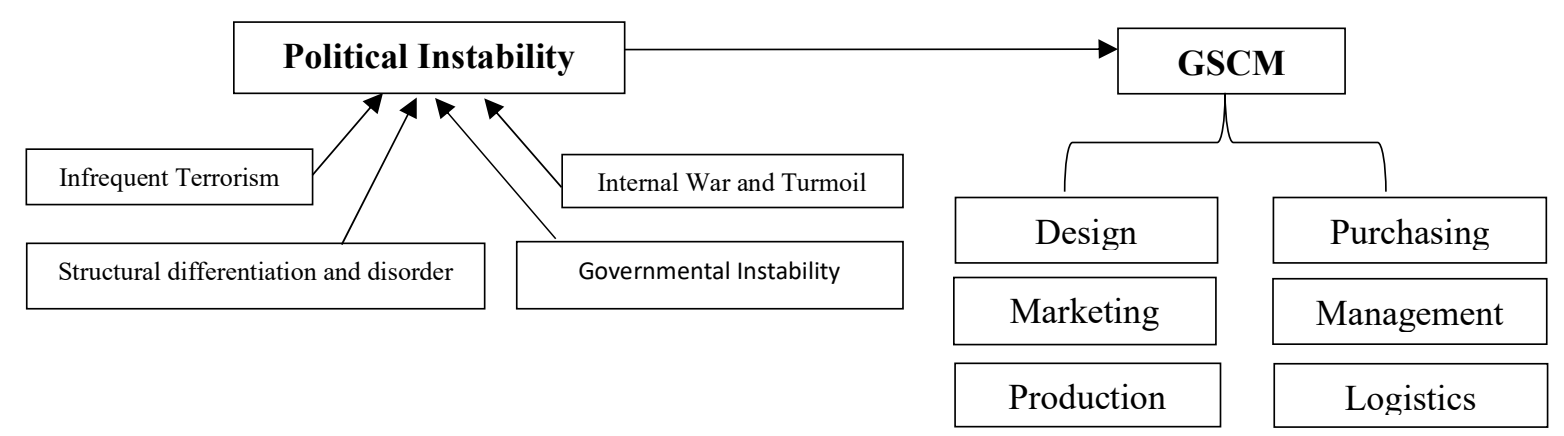

Fig. 2. Theoretical Model

\section{Analysis}

Our data was analyzed through SPSS version 23. Gathered data was tested based on demographic variables of the survey on its initial stage. The results show that from 265 respondents, a total number of 183 were male and 82 females. Additionally, age-range of respondents was shown to have the majority in 20-29 years old group with 35.2\%, followed by 30-39 years old group with $29.8 \%$. These were followed by 40 and above $(21.7 \%)$ and less than $20(13.3 \%)$. Moreover, our data show that majority of respondents hold a diploma degree (39.5\%), followed by undergraduate degree holders (33.8\%), and the residual held higher degrees $(\mathrm{PhD})(26.7 \%)$.

Table 2

Model Summary

\begin{tabular}{ccccc}
\hline Model & $\mathrm{R}$ & $\mathrm{R}$ Squared & Adjusted R Squared & Std. Error of the Estimate \\
\hline 1 & $.895^{\mathrm{a}}$ & .863 & .884 & .35805 \\
\hline
\end{tabular}

a. Predictors: (Constant), PI

Table 2 represents model summary conducted on the data with SSCM being the dependent variable. The calculated value of R-squared shows a significance in terms of explaining the variations of SSCM through PI.

Table 3

$\underline{\text { SL against SSCM dimension }- \text { Analysis of Coefficients }}{ }^{\mathrm{a}}$

\begin{tabular}{|c|c|c|c|c|c|c|}
\hline & \multirow[b]{2}{*}{ Model } & \multicolumn{2}{|c|}{ Unstandardized Coefficients } & Standardized Coefficients & \multirow[b]{2}{*}{$\mathrm{t}$} & \multirow[b]{2}{*}{ Sig. } \\
\hline & & $\mathrm{B}$ & Std. Error & Beta & & \\
\hline \multirow[t]{2}{*}{1} & (Constant) & .160 & .069 & & 2.413 & .014 \\
\hline & PI & .920 & .020 & .905 & -8.449 & .000 \\
\hline
\end{tabular}

a. Dependent Variable: SSCM (Production, Purchase, MGMT, MRKT, Logistics, Design)

Table 4

Model 1 regression - ANOVA $^{\mathrm{a}}$

\begin{tabular}{ccccccc}
\hline \multicolumn{2}{c}{ Model } & Sum of Squares & Df & Mean Squares & F & Sig. \\
\hline \multirow{2}{*}{1} & Regression & 340.871 & 1 & 310.871 & 170.752 & .000 \\
& Residual & 37.193 & 263 & .129 & & \\
\cline { 2 - 7 } & Total & 349.064 & 262 & & & \\
\hline
\end{tabular}

As it can be seen from Table 2, through regression model the assumption of negative impact on SSCM from PI is observable. In other words, the value of R Squared is as high as 0.863 , which means the variations of dependent variable has been explained up to $86.3 \%$ by the variations of independent variable. This supports our hypothesis as a negative t-value is calculated for SSCM against PI. Additionally, a high number of F value can be seen. A Pearson-two tailed correlation test was also conducted to further show the aforementioned effect in detail and in regard to dimensions of political instability.

\section{Discussion}

The results show that political instability had a negative and significant impact on SSCM practices within manufacturing industries of Palestine from employee perspective. While Table 5 shows that constructs used in this paper exhibit a satisfactory level of reliability $(\alpha)$ as well as construct reliability (CR) and average variance extracted (AVE), linear regression model and correlation test show that political instability as a factor had a vivid negative impact over sustainable practices within companies in manufacturing industry. Employees have perceived a strong relationship that reveals itself within the organizations 
that had considered and implemented sustainable and green activities. It is highly important to note that the extent of this negative impact is due to the difficulties caused by political instability and its dimensions. Major channels of distribution for logistics, production, management, marketing, purchasing, and design of green activities/products are disrupted and/or restrained due to complexities caused by chaotic and instable political state currently existing in Palestine. This is a major element in slowing managers and manufacturers in Palestine for taking initiatives regarding sustainability. Our results show that green design is the most affected element by political instability. This was discussed with managers of factories and seemingly, access to proper designing tools and technologies is extremely limited, which in turn decreases the eagerness of stakeholders towards sustainability. Our results are in line with similar studies in the literature as political instability was found to be an external (environmental) factor (Rostamzadeh et al., 2018). Furthermore, it supports the assumption that management of supply chain and particularly, sustainable activities in this regard becomes increasingly difficult due to existence of political instability. It is also to be considered that for a supply chain to progress, it requires to cross a number of borders that each can pose a threat towards the flow of process. Although political instability of each of those states is a significant factor that can cause problems for supply chain (Ghadar \& Moran, 1984; Prater et al., 2001; Rostamzadeh et al., 2018), stable states may also be of constraint as border control policies, requirements and procedures can be additional influential factors. In this regard, the EU has removed border controls, which as a result yields in smooth flow of processes regarding transference of goods among countries. These are contributors to the already complex state of supply chain management with regard to sustainability in countries with political instability. It is also to be regarded that regardless of aforementioned disruptions and limitations, manufacturers within Palestine have taken initiatives towards sustainability and green productions. New generations are encouraged to be aware regarding the environment and youth generation is being trained during first months of employment for better understanding the strategies of organizations in terms of sustainability and its practices. Uncertainty and complexity of political instability increases the exposure degree of supply chain with risky situations and disruptions. Political instability directly affects economic state, environment and social aspects of manufacturing processes within a country as well as its supply chain (Al-Damkhi et al., 2009). The damage that can be caused to facilities and infrastructure of the country is a major element contributing to exposure of supply chain and particularly, SSCM and its implementation in Palestine. This is consistent with similar findings (e.g. Al-Damkhi et al., 2009; Kleindorfer \& Saad, 2005; Wan Ahmad, et al., 2017).

Table 5

Loadings, AVE and Construct Reliability

\begin{tabular}{|c|c|c|c|c|}
\hline & FL & $\mathrm{CR}$ & $\alpha$ & AVE \\
\hline Structural Differentiation \& Disorder & & 0.83 & 0.81 & 0.550 \\
\hline SD1 & 0.743 & & & \\
\hline SD2 & 0.754 & & & \\
\hline SD3 & 0.768 & & & \\
\hline Infrequent Terrorism & & 0.84 & 0.81 & 0.630 \\
\hline IT 1 & 0.782 & & & \\
\hline IT2 & 0.772 & & & \\
\hline IT3 & 0.698 & & & \\
\hline Governmental Instability & & 0.81 & 0.83 & 0.629 \\
\hline GI1 & 0.719 & & & \\
\hline GI2 & 0.624 & & & \\
\hline $\mathrm{GI} 3$ & 0.774 & & & \\
\hline Internal War and Turmoil & & 0.82 & 0.84 & 0.561 \\
\hline IW1 & 0.821 & & & \\
\hline IW2 & 0.832 & & & \\
\hline IW3 & 0.718 & & & \\
\hline Green Design & & 0.76 & 0.85 & 0.531 \\
\hline Des1 & 0.617 & & & \\
\hline Des2 & 0.742 & & & \\
\hline Des3 & 0.688 & & & \\
\hline Green Purchasing & & 0.79 & 0.82 & 0.571 \\
\hline Pur1 & 0.546 & & & \\
\hline Pur2 & 0.645 & & & \\
\hline Pur3 & 0.784 & & & \\
\hline Green Management & & 0.81 & 0.80 & 0.612 \\
\hline Mgm1 & 0.628 & & & \\
\hline Mgm2 & 0.597 & & & \\
\hline Mgm3 & 0.647 & & & \\
\hline Green Marketing & & 0.80 & 0.79 & 0.598 \\
\hline Mrk1 & 0.645 & & & \\
\hline Mrk2 & 0.598 & & & \\
\hline Mrk3 & 0.690 & & & \\
\hline Green Production & & 0.79 & 0.78 & 0.601 \\
\hline Prod 1 & 0.578 & & & \\
\hline Prod2 & 0.623 & & & \\
\hline Prod 3 & 0.611 & & & \\
\hline Green Logistics & & 0.81 & 0.79 & 0.578 \\
\hline $\log 1$ & 0.602 & & & \\
\hline $\log 2$ & 0.590 & & & \\
\hline $\log 3$ & 0.678 & & & \\
\hline
\end{tabular}


Table 6

Pearson Correlation Test (Two-tailed)

\begin{tabular}{|c|c|c|c|c|c|c|c|c|}
\hline & & $\begin{array}{c}\text { Political } \\
\text { Instability }\end{array}$ & $\begin{array}{l}\text { Green } \\
\text { Design }\end{array}$ & $\begin{array}{c}\text { Green } \\
\text { Purchasing }\end{array}$ & $\begin{array}{c}\text { Green } \\
\text { Management }\end{array}$ & $\begin{array}{c}\text { Green } \\
\text { Marketing }\end{array}$ & $\begin{array}{c}\text { Green } \\
\text { Production }\end{array}$ & $\begin{array}{c}\text { Green } \\
\text { Logistics }\end{array}$ \\
\hline \multirow{3}{*}{$\begin{array}{l}\text { Political } \\
\text { Instability }\end{array}$} & Pearson Correlation & 1 & $-.915^{* *}$ & $-.658 * *$ & -.053 & $-.177 * *$ & -.016 & $-.514 *$ \\
\hline & Sig.(2 -tailed) & & .000 & .000 & .086 & .004 & .800 & .822 \\
\hline & $\mathrm{N}$ & 259 & 258 & 117 & 259 & 259 & 259 & 259 \\
\hline \multirow[t]{3}{*}{ Green Design } & Pearson Correlation & $-.915 * *$ & 1 & $.691^{* *}$ & .051 & $-1.69 * *$ & .004 & -.009 \\
\hline & Sig.(2 -tailed) & .000 & & .000 & .415 & .006 & .953 & .890 \\
\hline & $\mathrm{N}$ & 258 & 259 & 117 & 259 & 259 & 259 & 259 \\
\hline Green & Pearson Correlation & $-.658 * *$ & $.691 * *$ & 1 & .126 & .115 & -.109 & -.061 \\
\hline \multirow[t]{2}{*}{ Purchasing } & Sig.(2- tailed) & .000 & .000 & & .174 & .214 & .240 & .515 \\
\hline & $\mathrm{N}$ & 117 & 117 & 118 & 118 & 118 & 118 & 118 \\
\hline Green & Pearson Correlation & -.053 & .051 & .126 & 1 & -.025 & -.094 & .120 \\
\hline \multirow[t]{2}{*}{ Management } & Sig.(2- tailed) & .396 & .415 & .174 & & .691 & .131 & .053 \\
\hline & $\mathrm{N}$ & 259 & 259 & 118 & 260 & 260 & 260 & 260 \\
\hline Green & Pearson Correlation & $-.177 * *$ & $-.169 * *$ & .115 & -.025 & 1 & -.050 & $.133^{*}$ \\
\hline \multirow[t]{2}{*}{ Marketing } & Sig.(2- tailed) & .004 & .006 & .214 & .691 & & .420 & .032 \\
\hline & $\mathrm{N}$ & 259 & 259 & 118 & 260 & 260 & 260 & 260 \\
\hline Green & Pearson Correlation & -.016 & .004 & -.109 & -.094 & -.050 & 1 & .006 \\
\hline \multirow[t]{2}{*}{ Production } & Sig.(2- tailed) & .800 & .953 & .240 & .131 & .420 & & .918 \\
\hline & $\mathrm{N}$ & 259 & 259 & 118 & 260 & 260 & 260 & 260 \\
\hline Green & Pearson Correlation & $-.514 *$ & -.009 & -.061 & .120 & $.133^{*}$ & .006 & 1 \\
\hline \multirow[t]{2}{*}{ Logistics } & Sig.(2- tailed) & .822 & .890 & .515 & .053 & .032 & .918 & \\
\hline & $\mathrm{N}$ & 259 & 259 & 118 & 260 & 260 & 260 & 260 \\
\hline
\end{tabular}

**. Correlation is significant at the 0.01 level (2-tailed).

*. Correlation is significant at the 0.05 level (2-tailed).

\section{Study Limitations and Recommendations}

This study has faced a strong challenge regarding the existing data within the literature upon the matter as the notion of political instability lacks extensive research, while SSCM has taken a great deal of attention from scholars. Thus, this study urges further researchers to conduct examinations in similar states with political instability to further understand underlying effects and relationships. More advance statistical models or analyses can be used to further add other influential factors. This study was also limited in terms of measurement scales as political instability with regard to supply chain management does not present a strong case. Hence, experts of political areas and supply chain players can develop new measurements for specific examination of the issue at hand. This study was constrained by time as conduction and submission of this paper was time-bound. Future research can be conducted in several stages. Current paper was further limited in terms of comparative studies. This is despite the fact that several countries currently have political instability, where research on SSCM can be conducted.

\section{References}

Agarwal, G., \& Vijayvargy, L. (2012, March). Green supplier assessment in environmentally responsive supply chains through analytical network process. In Proceedings of International Multi Conference of Engineers and Computer Scientists, Hong Kong (Vol. 2, pp. 1-6).

Ahmad, N. K. W., de Brito, M. P., Rezaei, J., \& Tavasszy, L. A. (2016). An integrative framework for sustainable supply chain management practices in the oil and gas industry. Journal of Environmental Planning and Management, 60(4), 577601 .

Al-Damkhi, A. M., Abdul-Wahab, S. A., \& Al-Khulaifi, N. M. (2009). Kuwait's 1991 environmental tragedy: lessons learned. Disaster Prevention and Management: An International Journal, 18(3), 233-248.

Andiç, E., Yurt, Ö., \& Baltacıoğlu, T. (2012). Green supply chains: Efforts and potential applications for the Turkish market. Resources, Conservation and Recycling, 58, 50-68.

Azevedo, S. G., Carvalho, H., \& Machado, V. C. (2011). The influence of green practices on supply chain performance: a case study approach. Transportation Research Part E: Logistics and Transportation Review, 47(6), 850-871.

Azman, S. N., \& Jaafar, H. S. (2018). Supply chain disruptions that impact on factors of supply chain efficiency performance and competitiveness. Advances in Transportation and Logistics Research, 1(1), 266-278.

Bai, C., Sarkis, J., \& Dou, Y. (2015). Corporate sustainability development in China: review and analysis. Industrial Management \& Data Systems, 115(1), 5-40.

Balasubramanian, S. (2012). A hierarchiacal framework of barriers to green supply chain management in the construction sector. Journal of Sustainable Development, 5(10), 15-27.

Büyüközkan, G., \& Çifçi, G. (2012). Evaluation of the green supply chain management practices: a fuzzy ANP approach. Production Planning \& Control, 23(6), 405-418.

Castells, M. (2005). The network society: from knowledge to policy. The Network Society from Knowledge to Policy, 1, 1434. 
Cetindamar, D. (2001). The role of regulations in the diffusion of environment technologies: micro and macro issues. European Journal of Innovation Management, 4(4), 186-193.

Chaaban, F. B., \& Akkawi, M. (2013). National capacity self assessment for non-annex I nations: the case of Lebanon. International Journal of Energy Economics and Policy, 3(3), 199-209.

Collier, D. A., \& Evans, J. R. (2009). OM 2008: A Student-tested, Faculty-approved Approach to Learning Operations Management. Southwestern Cengage Learning.

Correlje, A., \& Van der Linde, C. (2006). Energy supply security and geopolitics: A European perspective. Energy policy, 34(5), 532-543.

Cox, S. R., \& Atkinson, K. (2018). Social Media and the Supply Chain: Improving Risk Detection, Risk Management, and Disruption Recovery.

Craighead, C. W., Blackhurst, J., Rungtusanatham, M. J., \& Handfield, R. B. (2007). The severity of supply chain disruptions: design characteristics and mitigation capabilities. Decision Sciences, 38(1), 131-156.

Doukas, H., Flamos, A., \& Psarras, J. (2011). Risks on the security of oil and gas supply. Energy Sources, Part B: Economics, Planning, and Policy, 6(4), 417-425.

Duarte, S., \& Cruz-Machado, V. (2015). Investigating lean and green supply chain linkages through a balanced scorecard framework. International Journal of Management Science and Engineering Management, 10(1), 20-29.

Dubey, R., Gunasekaran, A., Papadopoulos, T., Childe, S. J., Shibin, K. T., \& Wamba, S. F. (2017). Sustainable supply chain management: framework and further research directions. Journal of Cleaner Production, 142, 1119-1130.

Fattouh, B. (2007). How secure are Middle East oil supplies?. Oxford Institute for Energy Studies.

Fazli, S., Kiani Mavi, R., \& Vosooghidizaji, M. (2015). Crude oil supply chain risk management with DEMATEL-ANP. Operational Research, 15(3), 453-480.

G\&D Integrated. (2015). Defining Lean: 16 must-have metrics for any lean supply chain.

Garza-Reyes, J. A. (2015). Lean and green-a systematic review of the state of the art literature. Journal of Cleaner Production, 102, 18-29.

Govindan, K., Kaliyan, M., Kannan, D., \& Haq, A. N. (2014). Barriers analysis for green supply chain management implementation in Indian industries using analytic hierarchy process. International Journal of Production Economics, 147, 555568.

Green Jr, K. W., Zelbst, P. J., Meacham, J., \& Bhadauria, V. S. (2012). Green supply chain management practices: impact on performance. Supply Chain Management: An International Journal, 17(3), 290-305.

Gupta, D. (1990). The Economics of Political Instability: The Effect of Political Instability on Economic Growth. New York: Praeger.

Houshyar, A. N., Baghdadabad, M. R. T., Hoshyar, A. N., \& Sulaiman, R. B. (2013). Simulating Effects of Transportation Disruption on Supply Chain Based on Vendor Managed Inventory Approach. International Journal of Modeling and Optimization, 3(2), 116.

Huxel, P., \& Gelashvili, E. (2014). Use of lean and agile commercial supply chain practices in humanitarian supply chains. Umeå School of Business and Economics..

Janvier-James, A. M. (2012). A new introduction to supply chains and supply chain management: Definitions and theories perspective. International Business Research, 5(1), 194-207.

Ghadar, F., \& Moran, T. H. (1984). International political risk management: New dimensions. Washington, DC: Ghadar and Associates, and the Georgetown University School of Foreign Service.

Kleindorfer, P. R., \& Saad, G. H. (2005). Managing disruption risks in supply chains. Production and operations management, 14(1), 53-68.

Kotzab, H., Grant, D. B., \& Friis, A. (2006). Supply chain management implementation and priority strategies in Danish organizations. Journal of Business Logistics, 27(2), 273-300.

Kumar, N., \& Siddharthan, N. S. (2013). Technology, market structure and internationalization: issues and policies for developing countries. Routledge.

Kumar, S., Luthra, S., \& Haleem, A. (2013). Customer involvement in greening the supply chain: an interpretive structural modeling methodology. Journal of Industrial Engineering International, 9(1), 6.

Kumar, S., Luthra, S., \& Haleem, A. (2014). Critical success factors of customer involvement in greening the supply chain: an empirical study. International Journal of Logistics Systems and Management, 19(3), 283-310.

Kurdve, M., Shahbazi, S., Wendin, M., Bengtsson, C., \& Wiktorsson, M. (2015). Waste flow mapping to improve sustainability of waste management: a case study approach. Journal of Cleaner Production, 98, 304-315.

Li, G., Kang, Y., Liu, M., and Wang, Z. (2014). Optimal inventory policy under permissible payment delay in fashion supply chains. International Journal of Information System and Supply Chain Management, 1(4), 20-38.

Luthra, S., Garg, D., \& Haleem, A. (2014). Empirical analysis of green supply chain management practices in Indian automobile industry. Journal of The Institution of Engineers (India): Series C, 95(2), 119-126.

Luthra, S., Garg, D., \& Haleem, A. (2015). An analysis of interactions among critical success factors to implement green supply chain management towards sustainability: An Indian perspective. Resources Policy, 46, 37-50.

Luthra, S., \& Haleem, A. (2015). Hurdles in implementing sustainable supply chain management: An analysis of Indian automobile sector. Procedia-Social and Behavioral Sciences, 189, 175-183. 
Luthra, S., Garg, D., \& Haleem, A. (2016). The impacts of critical success factors for implementing green supply chain management towards sustainability: an empirical investigation of Indian automobile industry. Journal of Cleaner Production, 121, 142-158.

Markham, S. K. (2000). Corporate championing and antagonism as forms of political behavior: an R\&D perspective. Organization Science, 11(4), 429-447.

McKinsey (2010). How companies manage sustainability. McKinsey \& Company, USA.

Nachmias, C., \& Nachmias, D. (1992). Research Methods in the Social Sciences. $1^{\text {st }}$ ed. London: Edward Arnold.

Pakdil, F., \& Leonard, K. M. (2014). Criteria for a lean organisation: development of a lean assessment tool. International Journal of Production Research, 52(15), 4587-4607.

Pampanelli, A. B., Found, P., \& Bernardes, A. M. (2014). A Lean \& Green Model for a production cell. Journal of Cleaner Production, 85, 19-30.

Prater, E., Biehl, M., \& Smith, M. A. (2001). International supply chain agility - Tradeoffs between flexibility and uncertainty. International Journal of Operations \& Production Management, 21(5/6), 823-839.

Proto, A., Tani, S., Bühnemann, J., Gaus, O., \& Raith, M. (2012). Knowledge networks and their impact on new and small firms in local economies.

Qadri, M. A., Haleem, A., \& Arif, M. (2011). Identification of drivers for greening of supply chain in India. International Journal of Construction Project Management, 3(3), 213.

Rezaei, J., Kothadiya, O., Tavasszy, L., \& Kroesen, M. (2018). Quality assessment of airline baggage handling systems using SERVQUAL and BWM. Tourism Management, 66, 85-93.

Rostamzadeh, R., Ghorabaee, M. K., Govindan, K., Esmaeili, A., \& Nobar, H. B. K. (2018). Evaluation of sustainable supply chain risk management using an integrated fuzzy TOPSIS- CRITIC approach. Journal of Cleaner Production, 175, 651669.

Russell, R. S., \& Taylor, B. W. (2009). Operations management along the supply chain, $6^{\text {th }}$ ed., John Wiley and Sons (Asia) Pte Ltd.

Sarkis, J. (2012). A boundaries and flows perspective of green supply chain management. Supply Chain Management: An International Journal, 17(2), 202-216.

Seddighi, H. R., Nuttall, M. W., \& Theocharous, A. L. (2001). Does cultural background of tourists influence the destination choice? An empirical study with special reference to political instability. Tourism management, 22(2), 181-191.

Seddighi, H. R., \& Shearing, D. F. (1997). The demand for tourism in North East England with special reference to Northumbria: an empirical analysis. Tourism Management, 18(8), 499-511.

Seddighi, H. R., Theocharous, A. L., \& Nuttall, M. W. (2002). Political instability and tourism: an empirical study with special reference to the microstate of Cyprus. International Journal of Hospitality \& Tourism Administration, 3(1), 61-84.

Seuring, S., \& Müller, M. (2008). From a literature review to a conceptual framework for sustainable supply chain management. Journal of Cleaner Production, 16(15), 1699-1710.

Shujing, Q. (2012). The analysis on barriers of low carbon technology transfer. Energy Procedia, 14, 1398-1403.

Sundarakani, B., De Souza, R., Goh, M., Wagner, S. M., \& Manikandan, S. (2010). Modeling carbon footprints across the supply chain. International Journal of Production Economics, 128(1), 43-50.

Toke, L. K., Gupta, R. C., \& Dandekar, M. (2012). An empirical study of green supply chain management in Indian perspective. International Journal of Applied Science and Engineering Research, 1(2), 372-383.

Toppinen, A., \& Korhonen-Kurki, K. (2013). Global Reporting Initiative and social impact in managing corporate responsibility: a case study of three multinationals in the forest industry. Business ethics: A European review, 22(2), $202-217$.

Tseng, M., Lim, M., Wong, W.P., 2015. Sustainable supply chain management: a closed-loop network hierarchical approach. Industrial Management \& Data Systems115(3), 436-461.

Ugochukwu, P., Engström, J., \& Langstrand, J. (2012). Lean in the supply chain: a literature review. Management and production engineering review, 3(4), 87-96.

Van Der Vorst, J. G., Tromp, S. O., \& Zee, D. J. V. D. (2009). Simulation modelling for food supply chain redesign; integrated decision making on product quality, sustainability and logistics. International Journal of Production Research, 47(23), 6611-6631.

Wan Ahmad, W. N. K., Rezaei, J., Sadaghiani, S., \& Tavasszy, L. A. (2017). Evaluation of the external forces affecting the sustainability of oil and gas supply chain using Best Worst Method. Journal of Cleaner Production, 153, $242-252$.

Zhu, Q., Sarkis, J., \& Lai, K. H. (2012). Green supply chain management innovation diffusion and its relationship to organizational improvement: An ecological modernization perspective. Journal of Engineering and Technology Management, 29(1), 168-185.

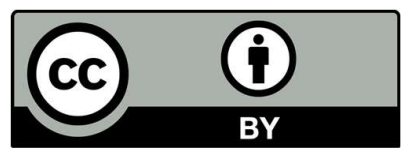

(C) 2020 by the authors; licensee Growing Science, Canada. This is an open access article distributed under the terms and conditions of the Creative Commons Attribution (CC-BY) license (http://creativecommons.org/licenses/by/4.0/). 